
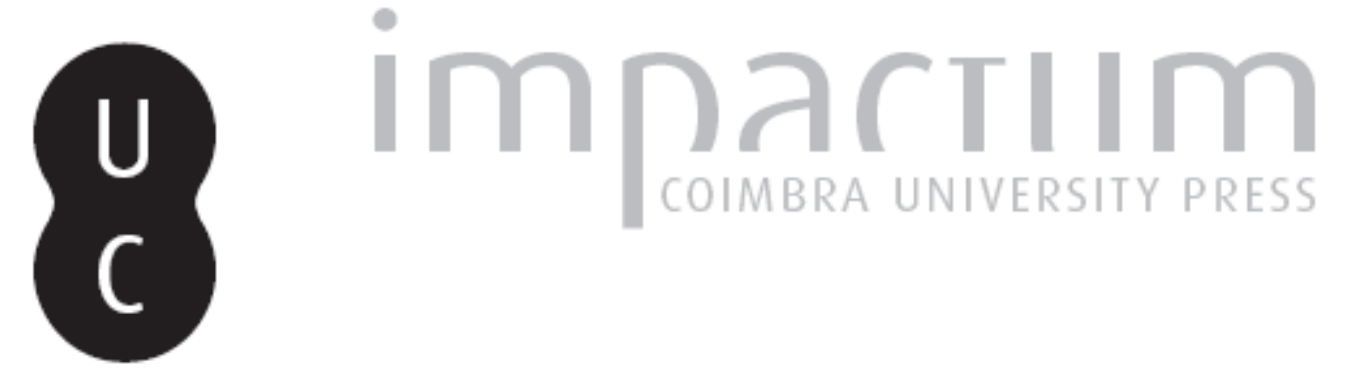

\title{
Paleopathological studies in the inner Abruzzo Region (Central Italy)
}
Autor(es):
Ventura, Luca; Leocata, Pietro; Mancinelli, Domenico; Miranda, Gaetano; Ventura, Terenzio

Publicado por: CIAS - Centro de Investigação em Antropologia e Saúde

URL persistente:

URI:http://hdl.handle.net/10316.2/41268

DOI:

DOI:http://dx.doi.org/10.14195/2182-7982_19_12

Accessed : $\quad$ 26-Apr-2023 16:06:47

A navegação consulta e descarregamento dos títulos inseridos nas Bibliotecas Digitais UC Digitalis, UC Pombalina e UC Impactum, pressupõem a aceitação plena e sem reservas dos Termos e Condições de Uso destas Bibliotecas Digitais, disponíveis em https://digitalis.uc.pt/pt-pt/termos.

Conforme exposto nos referidos Termos e Condições de Uso, o descarregamento de títulos de acesso restrito requer uma licença válida de autorização devendo o utilizador aceder ao(s) documento(s) a partir de um endereço de IP da instituição detentora da supramencionada licença.

Ao utilizador é apenas permitido o descarregamento para uso pessoal, pelo que o emprego do(s) título(s) descarregado(s) para outro fim, designadamente comercial, carece de autorização do respetivo autor ou editor da obra.

Na medida em que todas as obras da UC Digitalis se encontram protegidas pelo Código do Direito de Autor e Direitos Conexos e demais legislação aplicável, toda a cópia, parcial ou total, deste documento, nos casos em que é legalmente admitida, deverá conter ou fazer-se acompanhar por este aviso.

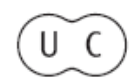


Antropologia Portuguesa

Volume $19 \cdot 2002$

Departamento de Antropologia | Universidade de Coimbra 


\title{
Paleopathological studies in the inner Abruzzo Region (Central Italy)
}

\author{
Luca Ventura' ${ }^{1}$, Pietro Leocata', Domenico Mancinelli ${ }^{2}$, Gaetano \\ Miranda ${ }^{2}$, Terenzio Ventura' \\ 1 U. O. di Anatomia Patologica, \\ City Hospital, 67100 L'Aquila, Italy \\ 2 Department of Environmental Sciences, \\ University of L'Aquila, Italy \\ luca.ventura@tin.it
}

Abstract In recent years we undertook a systematic study of human remains in the inner Abruzzo region, in order to create a map of the paleopathological material. This is a land of mountains and highlands with favorable climatic and environmental conditions for natural mummification. We investigated the mummified and skeletal remains of eight different series dated from the first millenium BC to the XIX century $A D$, some of which are presented for the first time in paleopathological literature. These series, along with others that we plan to study in the future, confirm that our region is one of great paleopathological interest.

Key words Paleopathology; osteoarcheological remains; Abruzzo region; natural mummies.

Resumo Nos últimos anos efectuámos um estudo sistemático dos restos humanos da região de Abruzzo (Itália) de modo a criar um mapa do material paleopatológico. Esta é uma regiāo de montanhas e terras altas com condições climáticas e ambientais favoráveis à mumificação natural. Investigámos os vestígios mumificados e esqueléticos de oito séries, algumas das quais apresentadas pela primeira vez na literatura paleopatológica, compreendendo um período que vai desde o primeiro milénio a.C. até ao século XIX. Estas séries, em conjunto com outras que planeamos estudar futuramente, confirmam o grande interesse paleopatológico da nossa região.

Palavras-chave Paleopatologia; região de Abruzzo; múmias naturais; vestígios osteoarqueológicos. 
The inner Abruzzo region, which roughly corresponds to the province of L'Aquila, is a land of mountains and highlands with a cold, dry climate. In 1997 we began a systematic study of human remains in this area, in order to create a map of the paleopathologic material (Ventura et al., 2001). The aim of the present study is to update the list of the known sites in this region of Italy (Figure 1).

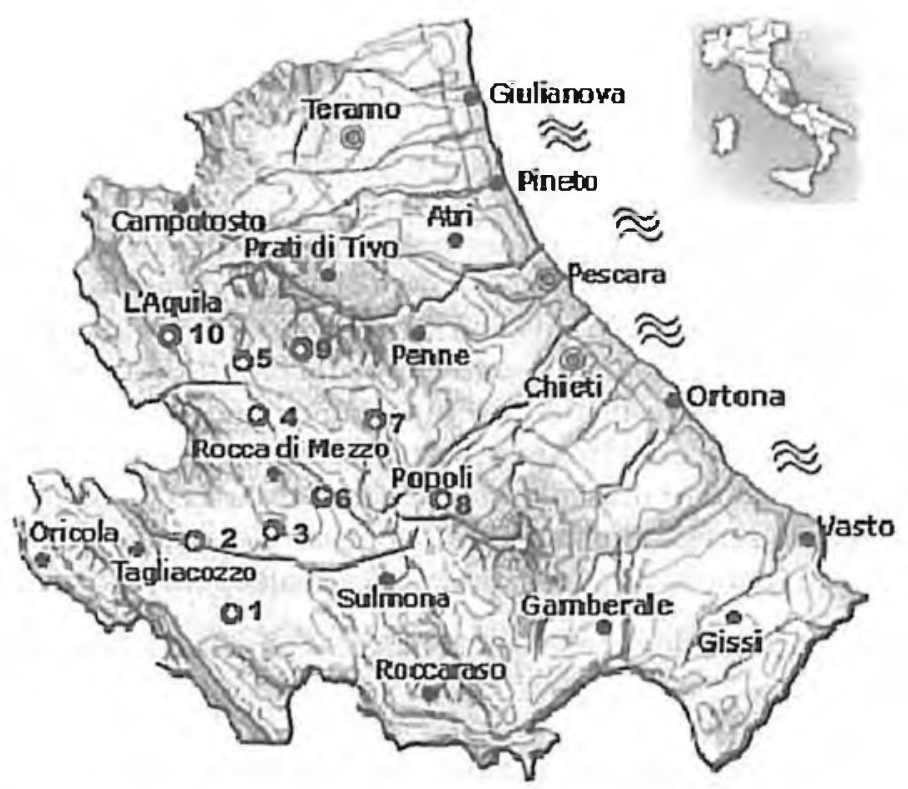

Figure 1. Map of paleopathological human remains in the inner Abruzzo region.

Starting from the western borders of the region, we investigated the burials near the church of Santa Maria delle Grazie in Luco dei Marsi (n.1 in Figure 1), which revealed 59 skeletons and 2 ossuaries found during a 3 year campaign (19992001). These remains, dated to the XV-XVI centuries, belonged to a rural population with high rates of osteoarthritis and periodontal disease (Leocata and Ventura, 2001). The study of osteoarcheological material from the ossuary of the ruins of the church in San Potito di Ovindoli (XIII century) and from the 
church of Santa Maria della Vittoria (XIV century) in Scurcola Marsicana (n. 2 and 3 in Figure 1) is still in progress. The paleopathological analysis of these samples will allow us to trace the health status of the medieval population of this particular geographic area.

The necropolis of Fossa Casale (n. 4 in Figure 1), investigated by archaeologists in 1992-2001, yielded the remains of 560 individuals dated to the IX-I Centuries BC. This skeletal series and the series from the necropolis of Bazzano (n. 5 in Figure 1) (about 800 individuals, dated to the VIII Century BC - I Century AD, investigated in the period 1993-2002) represent one of the largest population sample from the first millenium BC in Italy. Paleopathological study of these remains is still in progress.

We studied the natural mummies of four XIX century individuals found in the friary of San Giorgio degli Osservanti (XVIII century) in the village of Goriano Valli (n. 6 in Figure 1). These well-preserved natural mummies, dating back to XIX century, were studied by computed tomography and by autopsy. In this series we were able to demonstrate thyroid goiter, prostatic hyperplasia and pulmonary tuberculosis in 50-60 year-old man, an osteochondroma of the distal femur in an adult woman, and a case of possible functional obstruction of the rectum in an elderly man also affected by DISH (Leocata et al., 1999; Ventura et al., 1999).

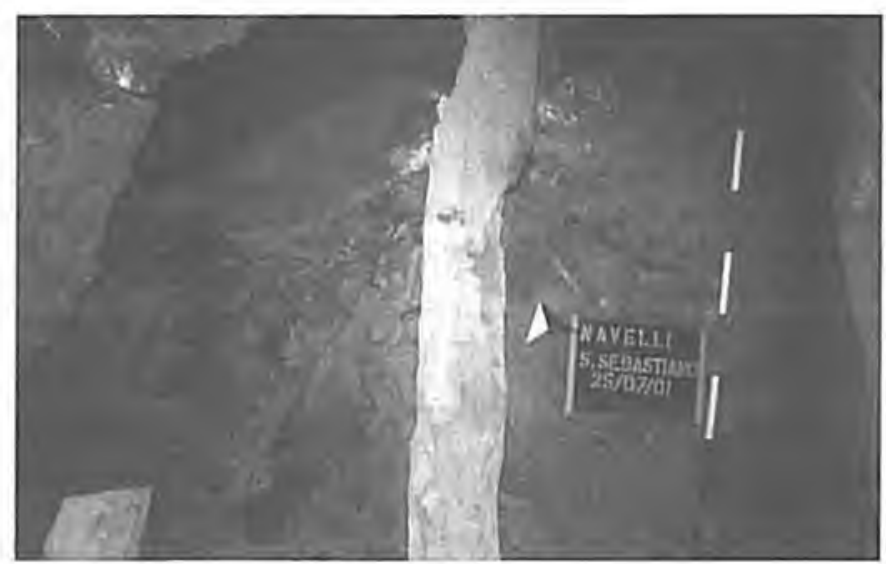

Figure 2. One of the crypts beneath the church of San Sebastiano in Navelli. 
In 2001, we began the recovery of human remains found in the crypts beneath the church of San Sebastiano in Navelli (n. 7 in Figure 1; Figure 2). Hundreds of mummified or skeletonized bodies dated to the XVI - XIX centuries were accidentally discovered in 1980 but, since then only a preliminary investigation has been made (Capasso and Di Tota, 1991) because of the lack of funds and interest by the local organizations. As soon as the recovery has been completed, a huge amount of information about this community will be available.

The series from the church of the Santissima Trinità in Popoli (Pescara province) (n. 8 in Figure 1) includes at least 8 mummified or skeletonized bodies dating back to the XVIII century, buried in a crypt. A preliminary investigation of these mummies took place in 2001, documented by the National Geographic Society in their educational television program, "The Mummy Road Show". Further details of this study were presented at the XIV Biennial Meeting of the Paleopathology Association in Coimbra, Portugal (Ventura et al., 2002).

An interesting new site that we hope to study in the near future is located in the village of Filetto (n. 9 in Figure 1), where many mummified human remains were found in an old ruined church of the XIV century, destroyed during the siege by Braccio da Montone (1424 AD) and never rebuilt. It may contain a significant portion of the population living in Filetto at that time.

The natural mummies of the Castello Cinquecentesco in L'Aquila (n. 10 in Figure 1) include four XVI century individuals ( 2 women, a boy and a girl), who have not yet been investigated. These bodies are part of a larger sample of about one hundred mummies found in 1902 in a chapel of the castle and later reburied in the cemetery by order of the Archbishop.

Along with these collections of individuals, the remains of some remarkable figures resting in L'Aquila must be noted. The body of Saint Bernardino da Siena represents an interesting example of the embalming techniques during the Renaissance period. Among the historical figures of the XV century, the mummified bodies of the Blessed Jean Bassand, Antonia da Firenze, and Vincenzo dell'Aquila also repose in our town. In the 
basilica of Santa Maria di Collemaggio, the relics of Saint Pietro da Morrone (Pope Celestino V) represent the basis for an historical case. The hole in his skull has raised many questions about the death of this saint and should be investigated completely in the future.

The presence of so many subjects for study represents a rich cultural heritage and an exciting stimulus for anthropological studies, giving us the opportunity to consider our region as one of great paleopathological interest.

\section{Acknowledgments}

This study was partially supported by a grant from the "Consorzio Beni Culturali della Provincia dell'Aquila".

\section{Bibliography}

Capasso, L.; Di Tota, G. 1991. The human mummies of Navelli: natural mummification at new site in central Italy. Paleopathology Nezusletter, 75: 7-8.

Leocata, P.; Ventura, L. 2001. Paleopatologia dei resti scheletrici di S. Maria delle Grazie a Luco dei Marsi. In: Campanelli, A. (ed.). Il tesoro del lago. L'archeologia del Fucino e la collezione Torlonia. Pescara, CARSA Edizioni: 304-305.

Leocata, P.; Ventura, L.; Michelini, O.; Ventura, T.; Pasqua, M.; Fornaciari,

G. 1999. Paleopathologic study of four nineteenth-century mummies from Goriano Valli (L'Aquila, Italy). Abstracts of papers presented at the XIIIth European Meeting of the Paleopathology Association, Chieti, Italy, 18-22 September 2000. Journal of Paleopatiology, 11(2): 66. Ventura, L.; Fornaciari, G.; Leocata, P.; Colimberti, P.; Alonzi, C.; Ventura T 1999. Multinodular goiter and pulmonary tuberculosis in a nineteenthcentury Italian. Abstracts of papers presented at the XIIIth European Meeting of the Paleopathology Association, Chieti, Italy, 18-22 September 2000. Joumal of Paleopathology, 11(2): 119-120.

Ventura, L.; Leocata, P.; Beckett, R.; Conlogue, G.; Sindici, G.; Calabrese, A.; Di Giandomenico, V.; Fornaciari, G. 2002. The natural mummies 
of Popoli. A new site in the inner Abruzzo region (Central Italy). In: 14th Europenn Meeting of the Paleopathology Associntion: Program Abstract. Coimbra, 28-31 August 2002. Coimbra, Departamento de Antropologia, Universidade de Coimbra: 167.

Ventura, L.; Leocata, P.; Sindici, G.; Diana, M.; Ventura, T. 2001. Paleopathologic map of the inner Abruzzo region (Italy). Abstract of paper presented at the XVI Meeting of the Adriatic Society of Pathology, Rimini, Italy, 22-24 June 2001. Advances in Clinical Pathology, 5: 19-20. 